\title{
A EVOLUÇÃo HISTÓRICA DA FILOSOFIA
}

\author{
Eduardo Carlos Bianca Bittar \\ Aluno do Curso de Graduação da Faculdade de Direito da USP
}

Resumo:

A evolução do pensamento filosófico na história processou-se sob etapas definidas, mediante contribuições dos mais eminentes vultos do saber humano, tendentes à detecção do próprio sentido da vida humana em sociedade. Na Antiguidade, voltaram-se os pensadores para a política, com destaque para os trabalhos de Platão e Aristóteles. A Idade Média foi, predominantemente, a era da contemplação ou da filosofia dirigida à descoberta da essência de Deus, com ênfase para as obras de Santo Agostinho, São Bento e Santo Tomás. A Idade Moderna representou a da afirmação dos direitos fundamentais no aperfeiçoamento do convívio social, com Locke, Rousseau, Voltaire e Montesquieu. Na Idade Contemporânea destacam-se o assentamento dos valores sociais e religiosos que devem inspirar o convívio humano, principalmente com os trabalhos de Max Weber e Émile Durkheim. Presente em todas as épocas e em todos os pensadores, está a busca e a identificação do Bem-Comum, aliás, preocupação universal e perene do próprio espirito humano.

Abstract:

Philosophy has evolved step by step due to the contribution of the people who have searched for the meaning of social life. In anciente times, philosophers were concerned with politics and the most important words were those brought out by Platon and Aristotle. In the Middle Ages, philosophy was characterized by contemplation, for it was channeled to the search of the essence of God; the works by Santo Agostinho, São Bento and Santo Tomás* were the most important ones. After the Middle Ages, philosophers such as, for instance, Locke, Rousseau, Voltaire and Montesquieu - turned out to be concerned with the consolidation of the fundamental rights. From the French Revolution, there has been a continuous strength of the social and religious values inspiring social life, thanks to Max Weber and Émile Durkheim. Thus, it can be said that the search for the concept of well-being has been universal and perennial.

*Nota: Os nomes foram mantidos em português. 
SUMÁRIO

1. Idade Antiga

2. Idade Média

3. Idade Moderna

4. Idade Contemporânea

"(..) Que todos aqueles a quem o engenho e o estudo habilitam para os graves e profundos trabalhos da história se dediquem a ela. (...) Exercitem-no os que podem e sabem, porque não o fazer é um crime."

(Alexandre Herculano, $\mathrm{O}$ Bobo)

\section{Idade Antiga}

Para a compreensão do alcance da filosofia no mundo ocidental, imprescindível se faz volvamos nossas atenções para a Antiguidade grega, responsável pelo surgimento das primeiras especulações a respeito do homem, daquilo que lhe é tangível e daquilo que transcende a sua capacidade sensorial, como, v.g., nos fecundos pensamentos socráticos, legados imorredouros do gênio humano. A análise histórica permitir-nos-á entender a gradativa construção desta civilização e do incomensurável edifício cultural erigido em seu seio.

$\mathrm{O}$ mundo egeu, anterior ao século XX a.C., era caracterizado pela talassocracia creto-micênica, civilização exuberante, comercial e artisticamente, que viria a compor o próprio corpo da futura Grécia. A esse tempo, iniciavam-se as invasões dos aqueus, perpetuadas pelas dos jônios e eólios (séc. XVIII a.C.), findando-se com a fixação dos dórios na região (séc. XII) do Peloponeso e em Creta. Um período de assentamento e acomodação é sucedido por um de expansão e colonização no século VIII a.C. Época de misticismo, de completa submissão do homem às forças naturais totalmente incompreensíveis, onde a religião fantástica da mitologia compunha um quadro de cores desconhecidas, ocupando o homem mera posição de espectador do incognoscível.

A organização social apoiava-se nos núcleos familiares irredutíveis (genes), que, agrupados, compunham as fratrias e um número menor de quatro tribos. Uma divisão social estática e baseada nos poderes inoponíveis do chefe de 
família, regida e controlada pela tradição, pela hereditariedade, pela subordinação nas relações de parentesco, pelos laços da cognatio, pela propriedade da terra. Com um convívio social pouco desenvolvido, a vida privada era considerada a inteireza das relações humanas, limitando-se ao labor, no sentido arendtiano do termo, à atividade de subsistência e perpetuação da estrutura comunitário-familiar. Desligando-se das concep̧̧ões fantasiosas e míticas, o homem grego inicia a busca da unidade e dos elementos geradores do universo. São os pré-socráticos e a perquirição em torno do significado da physis.

Paulatinas modificações vão alterando e conduzindo a constantes crises a estrutura gentílica grega. As mal-sucedidas reformas empreendidas por Sólon não conseguem vedar as evidentes fissuras que concorriam para o esfacelamento de tal estrutura estática. $\mathrm{O}$ rígido imobilismo afigurava-se como entrave a uma sociedade que alargava seus horizontes e expandia suas influências por todo o mundo conhecido de então.

Em 509 a.C., Clístenes rechaçou as invasões persas e instaurou uma grande reforma estrutural que haveria de alterar toda a configuração predominante. A sociedade que venceu os persas passou pela experiência da guerra, elemento de revolução social, capaz de bombardear o núcleo familiar e seus laços tradicionais de coesão e estabelecer a submissão única à autoridade do líder militar. Desta forma, desarticulada a engrenagem baseada no poder paternal, o mundo grego abriu-se para uma nova fase de sua história, onde estavam presentes os elementos que a tornaram o ideal cultural e político do Ocidente: liberdade de pensamento, individualismo criativo, intensa vida política, exaltação do militarismo, cidadeestado, efervescência artística, filosófica e cultural.

O século V a. C., mais conhecido como Século de Péricles, constituiu o auge da civilização grega, correspondendo a um período de intensa racionalização, de fecunda produção artística e científica, momento em que se intensificou a busca do belo artístico ideal da consagrada escultura grega. Nesse ínterim, Sócrates (469-399 a.C.), o mestre dos pensadores gregos, iniciou suas pregações pelas ruas de Atenas aos jovens, utilizando-se do método maiêutico de parturição das idéias, que considerava inatas ao homem. Desta forma, o insigne filósofo grego, dotado de método dialético especial, fazia com que a verdade emergisse do âmago de ser. Combateu o método sofista do discurso robusto pela eloqüência e pela retórica, mas vazio de conteúdo. Encarando sua vida como uma 
missão ditada pelo oráculo de Delfos, Sócrates pregou com veemência o "nosce te ipsum" mas tendo consciência de que só "sabia que nada sabia". Segundo sua concepção, o sábio seria aquele que procurasse em todos os momentos: distanciar-se da escravidão aos bens materiais, à luxúria, à gula, ao sono, ao ócio improdutivo; ampliar sua amizades e auxiliar os amigos em necessidade; viver segundo o Belo e o Bom; respeitar as leis; aprimorar-se no convívio e auto-conhecer-se; respeitar o passado, os costumes e tradições...

Mas o conjunto de idéias pregadas por Sócrates contrastavam com os anseios da sociedade relativamente democrática de sua época, assim como seu método de parturição das idéias provava constantemente a ignorância de pretensos sábios e eminentes políticos, igualando intelectualmente o servo ao senhor que, socialmente eram desiguais. Essa sociedade preconceituosa e irritada com a retórica incisiva, como era a de Sócrates, condenou-o a beber cicuta em 399 a.C., acusandoo injustamente de deturpar a juventude, negar os deuses da cidade e de criar novas divindades. Antes de sua morte, o grande pensador já apontava a decadência de um mundo de aparências prósperas e inabaláveis, pois o afrouxamento do sentimento patriótico e o do desrespeito para com o passado minavam os alicerces da cidadeestado grega.

A realidade vivida por Platão (427-347 a.C.) é muito distante daquela vivida por seu mestre. Após a Guerra do Peloponeso (431-404 a.C.), onde confrontaram-se as forças democráticas e oligárquicas do mundo grego, Platão presenciou a vitória de Esparta e a imposição de regime aproximado ao da oligarquia sobre Atenas (Trinta Tiranos). A restauração da democracia em 403 a.C. renovou o ânimo do filósofo, mas este se viu decepcionado quando esses mesmos democráticos governantes julgaram e condenaram o maior expoente do pensamento grego: Sócrates. Traído em suas aspirações iniciais, Platão sufocou sua vocação política e passou a dedicar-se à filosofia, utilizando-se do método aprendido com seu mestre (diálogos dialéticos).

Diante da pólis desagregada, da política faccionada, do discurso retórico vazio, do particularismo, do predomínio das paixões no espaço público, assim como da decadência dos valores, Platão firmou suas expectativas políticas sobre um pedestal monolítico, baseando suas propostas na supremacia da filosofia política. A seqüência enorme de diálogos por ele escritos compôs a evolução do seu pensamento, de maneira geral oposto às tendências de sua época. 
O Estado, em sua concepção, não existe para abastar os indivíduos de riquezas materiais, mas serve, antes de tudo, para o aprimoramento moral de seus cidadãos. $O$ bem do Estado é o bem dos particulares, que só pode ser conseguido pelo governo das leis. Também o governante deve assumir o controle das atividades políticas, pois ele é o sábio educado dentro de uma disciplina especial para proporcionar o desenvolvimento racional da cidade-estado. Destarte, os cidadãos devem distanciar-se da vida política (ação), que é um campo por demais instável, sujeito à ditadura da opinião (doxa), sujeito a inúmeras disputas e controvérsias que colocariam em risco a estabilidade da monumental cidade-estado platônica. A família seria eliminada para que o sentimento comunitário fosse semeado, procurando uma expansão do âmbito privado a um corpo comum a todos os cidadãos que viveriam exclusivamente para o labor e para o trabalho (homo faber e animal laborans). É, então, uma comunidade monolítica e unitária, contrariamente à cidade de sua época, regida pelo filósofo, contrariamente ao faccionismo político (Arendt, Hannah. A condição humana, 1989, p. 23-30).

De outra forma, exaltava a necessidade do escravo na pólis ideal, pois a presença deste liberaria o filósofo para a vita contemplativa, assim como para a ação na ágora ateniense. Estas duas atividades eram compreendidas como constituintes da vita activa, da qual estavam ausentes o labor e o trabalho, condições que prendem o homem à esfera de manutenção da vida, que incessantemente consome tudo e torna o ser vassalo da natureza. O filósofo-sábio deve estar isento do labor e do trabalho para que possa eternizar a sua passagem pelo mundo através da construção intelectual, ou da ação política reificada em obra escrita. A morte de Sócrates inclusive, passou a representar um marco importante na história do pensamento, uma vez que nesse momento surgiu a distinção entre ação e pensamento. Em outras palavras, a eternidade é uma prerrogativa dos deuses e constitui a não-mortalidade, enquanto que a imortalidade é uma capacidade humana de perenizar seus atos e feitos através da ação política (reificada) ou de seu pensamento escrito (vida contemplativa), em conformidade com o que nos informa Hannah Arendt (ob. cit., p. 24). Platão incumbiu-se de imortalizar a philosophia perennis de Sócrates, que nada havia deixado escrito.

Desta maneira, Platão procurou reorganizar uma sociedade em desagregação em virtude da perda da consciência coletiva, que fazia com que os particularismos conduzissem ao distanciamento do Bem-Comum. Este só poderia 
ser alcançado quando se alcançasse a Verdade, um critério que transcendesse ao sensível e imperasse harmonicamente para o bem da cidade. Assim, da multiplicidade material poder-se-ia alcançar o Uno (mundo das Idéias), que serviria de exemplo para a conduta dos indivíduos na multiplicidade da pólis. Vislumbra-se - Belo, kalos, para que se governe segundo o Bem, agathós (dialética da multiplicidade-uno). Deve-se, a partir das sombras, buscar a razão das ciências, até que se alcancem as idéias verdadeiras, o Inteligível.

De outro lado, a alma humana é composta por paixão, coração e razão, que correspondem, respectivamente, no mundo social, aos profissionais da esfera econômica, aos soldados e ao dirigente-filósofo. Desta forma ordenada, a sociedade caminharia inexoravelmente para a divinização, para a sublimação, alcançando-se o Bem-Comum, onde o coletivo primaria sobre o particular e onde o bem de todos constituiria o bem de cada um.

A Guerra do Peloponeso (431-404 a.C.), ao lado de outros fatores, contribuiu para o enfraquecimento do mundo grego, que se via imerso em intermináveis querelas intestinas. $\mathrm{O}$ ocaso não tardou e as fronteiras acabaram expostas a um inimigo externo comum, que, agora, se afigurava um enorme gigante, crescente em territórios, riquezas e poder: o universo macedônico. A subjugação dos gregos iniciou-se com Felipe II, logo sucedido por seu filho, Alexandre, o Grande, dotado de singular astúcia bélica, em muito conseqüência de um aprendizado orientado por Aristóteles. Diante de tal situação, presenciando a Grécia submissa ao poder imperial unificado, o Mestre do Liceu (384-322 a.C.) apresentou uma teoria em muitos pontos diametralmente oposta à de seu mestre, Platão, entre outros motivos, por se situarem em momentos históricos diferenciados.

A priori, segundo a concepção do eminente estagirita, o homem é um ser social. Isto implica a ligação do ser humano a uma esfera exclusivamente privada. Assim, o homem nasce em família, vivendo unicamente para a condição do labor (necessidade), unido por vínculos de subordinação ao chefe de família. Ao passar para o convívio na pólis, é acrescida à condição do labor, a da ação, inaugurando a fusão entre o mundo privado e o público. Dentro de um ambiente de coordenação, a ação política na agorá torna-se meio de alcançar virtuosismo público e eternidade de pensamento. Neste meio da ação, a imprevisibilidade é oriunda da condição da natalidade, forma de introdução de novidades e mudanças 
sempre crescentes. Esta passagem do social para o político constitui um salto qualitativo de vida adicionado à condição humana, uma vez que a única forma de combate à efêmera passagem humana sobre o mundo é a publicização de suas ações. Ao lado do mestre Platão, o discípulo vê com os mesmos olhos a virtude da vita contemplativa acrescida da ação política, pois esta é a época em que predomina a exaltação do ócio, proporcionado pela posse abundante de bens, condição que permitia desdenhar a necessidade ininternupta do labor.

O homem social do convívio familiar integra-se espontaneamente à civitas, pois é um politikon zoon. Desta forma, o Estado é anterior aos indivíduos, pois sua concepção já é algo inerente à natureza humana. A sociabilidade do homem confere-lhe a capacidade de desabrochar seus dons imanentes no convívio permanente. $\mathrm{O}$ governo ideal deve estar voltado para as leis, para, desta forma, alcançar a felicidade para o grupo social dele dependente. O particular também deve procurar o melhor para o coletivo, idéia já presente em Platão. Diferentemente, a propriedade privada, abolida em $A$ República, encontra lugar especial em $A$ Politica aristotélica, pois é considerada incentivo para o desenvolvimento intelectual humano. O comunismo platônico representaria o fim dos esforços que concorrem para a pesquisa, para o trabalho e para o aperfeiçoamento humano. Mas a escravidão encontra-se tão necessária como na teoria de Platão.

O pluralismo aristotélico opõe-se ao monolitismo do Império macedônico, visto burocrático e desunido. Este mesmo monocefalismo obscurece a política; a participação dos cidadãos foi reduzida à mera submissão às ordenações imperiais. Desta forma, dentro da teoria do célebre Estagirita, o Bem-Comum é possível de ser alcançado através da concorrência de esforços conjuntos, mas com a utilização de mecanismos de outra forma entendidos como superiores. A família, a amizade (philía), o amor, o casamento e a propriedade privada retornam como elementos imprescindíveis para a construção da felicidade mundana.

O helenismo alexandrino, que destruiu a identidade grega, baseada na vida política, provocou o degringolar da filosofia a ela ligada, ao mesmo tempo em que surgiram novas tendências intelectuais de caráter introspectivo e particularizante: é a filosofia da alma, identificada nas correntes do epicurismo, do estoicismo e do pirronismo. 
Diretamente influenciada pela cultura grega, floresceu a civilização; apesar do manto poético e mitológico que envolveu a fundação de Roma, esta deve sua origem à conjunção de inúmeros povos que habitavam a Península Itálica entre os séculos X e VIII a.C. (considera-se a data de 754 a.C.). Recebendo os legados culturais de etruscos e gregos, os romanos viriam a formar um exuberante Império, que haveria de extravasar as muralhas da antiga e fortificada Alba Longa, situada às margens do Tibre. À fundação da sede romana sucedeu-se um período de política régia, onde as forças de sabinos e etruscos alternaram-se no governo da cidade. $\mathrm{O}$ advento da República, em 509 a.C., representou um golpe efetuado e planejado pelos eupátridas romanos, que dividiram as propriedades e estruturaram a sociedade da maneira que prevaleceria por mais alguns séculos.

Pertencentes a uma fase que pode ser chamada de arcaica dentro da história da evolução do povo romano, esses períodos políticos foram intensamente marcados por valores imanentes a uma sociedade restrita em suas relações e pouco afeita a mudanças do status quo. O gradativo avanço das fronteiras no sentido da colonização, o afluxo de riquezas e escravos, o contato com a guerra e com o poder centralizado do dirigente militar iriam solapar a frágil solidez do direito consuetudinário e dos laços de família.

Cumpre-se destacar que pouca expressão encontrava o âmbito público, diante da grandeza maior reinante no âmbito privado: a do pater familias. $O$ chefe de família tinha, a priori, poderes ilimitados exercidos sobre seus dependentes e sobre suas propriedades exercidas na totalidade de direitos (usque ad sidera et ad inferos). Era o único cidadão de plena capacidade jurídica e de exercício de suas faculdades civis, enquanto que aqueles que dele dependiam eram considerados alieni iuris. Em sua condição de sui iuris, deveria zelar pela manutenção do patrimônio familiar e a ele cabia realizar todo e qualquer tipo de transação econômica, pois tudo que se adquiria, fazia-o para o pater familias. A representação social da família, assim como a perpetuação do culto religioso do lar eram encargos também de sua competência. Aliás, a manutenção do fogo divino aceso, como também os ritos do casamento, do nascimento e da morte eram interpretados como compromissos religiosos de sumo significado. $O$ poder público não poderia interferir ou contrastar com o poder do pater, que era considerado superior, sendo a esfera privada inatingivel por autoridade outra qualquer, que não a do próprio chefe de familia. A justiça privada era por ele ministrada, presidindo 
as solenidades do tribunal de julgamento de escravos, devedores insolventes ou de injuriadores da honra imaculável do brasão familiar. Esse representante legal era o único que poderia alcançar a exaltação pública através de seus feitos memoráveis no espaço público.

É de se notar que os escravos, ao lado dos clientes e familiares, também estavam incluídos como membros do núcleo familiar. Eram considerados rei, ou seja, objetos de direito, destituídos de direitos civis e proibidos de realizarem casamento (suas relações afetivas não eram reconhecidas pelo direito civil). Estavam circunscritos às atividades do labor interminável da luta pela sobrevivência; ocupavam uma posição considerada indigna de um verdadeiro ser humano.

O casamento de um cidadão era entendido, a princípio, como um dever cívico de perpetuação da comunidade, tarefa desempenhada tradicionalmente como forma de prolongamento de sua própria casta. $\mathrm{O}$ abrandamento dos costumes fez com que fosse entendido mais como uma relação de fato para a qual concorriam dois elementos primordiais determinantes de sua existência: honor matrimonii e affectio maritalis.

À vida pós-morte era atribuído pouco valor, cabendo à filosofia especuladora (speculare) da felicidade a tarefa de perquirir sobre assunto tão pouco conhecido peio homem comum. O homem, mortal e racional, segundo uma visão mitológica, compartilhava da morada mundana com os animais, seres mortais e irracionais, ao lado dos deuses, imortais e racionais. Os epitáfios e esculturas romanas comprovam a atribuição de um valor maior à vida terrena e aos momentos de glória e prestígio experimentados neste mundo, do que a uma realidade sobrehumana posterior a esta (Ariès, Philipe \& Duby, Georges. História da vida privada, 1990, v. 1, p. 201-23).

A promulgação da Lei das XII Tábuas, a 451 a.C., representando a vitória das aspirações populares por mudanças, comprovou a ineficácia da aplicação indubitável de regras rígidas e não-escritas do ius civile. O avanço da hegemonia romana sobre o Mar Mediterrâneo ocasionou o confronto e a subjugação das forças cartaginesas, selando o fim de um período marcado pelo modo de vida simples, rural e moralizado, e a passagem para a vitória militar, para o luxo, a ostentação e intensa vida pública, assim como de miséria e desemprego para o povo, devidos ao afluxo incontrolável de riquezas e escravos de guerra. 
A política expansionista da República Romana permitiu a concentração gradativa de poderes pelos generais, culminando com a oficialização do Império em 27 a.C., façanha do grande líder militar Otávio Augusto. Avocando a posição de Imperator Caesar divi filius Augustos (condecoração política máxima) e de Pontifex Maximus, Otávio desfechou o golpe final sobre toda a antiga e corroída estrutura patriarcal romana. Iniciou-se uma nova fase de predomínio do militarismo, de intensa politização e de grande desenvolvimento do Direito Romano. As próprias tendências sociais já se encontravam amenizadas e afeitas à flexibilidade, à renovação, ao abrandamento do rigor e à restrição do alcance quase infinito dos poderes paternais. $\mathrm{O}$ direito tornou-se muito mais penetrante na esfera privada e prerrogativa exercida pelo Estado, não circunscrevendo às normas exclusivas do ius civile, mas recebendo novos rumos com a introdução do ius gentium, do ius honorarium e do ius extraordinarium, onde o pretor desempenhou papel importantíssimo. O culto religioso tomou vulto no templo público, ao mesmo tempo em que o divórcio, a adoção, a emancipação, a alforria tornaram-se fatos muito mais presentes e constantes. Em suma, o tradicionalismo patriarcalista teve suas forças reduzidas diante do poder de imperium exercido pelo imperador.

Esse período de renovação passou a representar o esplendor do povo romano. A riqueza era entendida como uma grande virtude, aspiração de todo cidadão, capaz de proporcionar o ócio, que permitia a libertação da condição humana da necessidade para a ação política e para a contemplação filosófica, a exemplo dos gregos. A projeção social no espaço público advinha da promoção de grandes espetáculos populares ou da utilização da riqueza privada para a construção de monumentos que houvessem de embelezar a sede do faustoso império. Desta forma, a distinção entre público e privado não era nítida, conduzindo o eminente cidadão a dispensar contínuos esforços para a manutenção de um ambiente público luxuriante. Havia uma igualdade entre os membros da classe aristocrática imperial que os compelia à união, à coesão entre si. De qualquer forma, os banquetes, os banhos públicos, os espetáculos eram sempre freqüentados como partes de uma vida pública intensa e de grandes contatos sociais. A educação dada aos filhos púberes voltava-se para a ação política, para a busca de prestígio social, e era ministrada segundo o aprendizado da retórica, da oratória, do grego, dos autores clássicos e da mitologia. Esses conhecimentos permitiam a participação no mundo político. 
O surgimento do Cristianismo no século I d.C. representou o nascimento da filosofia religiosa no mundo ocidental. $\mathrm{O}$ momento histórico de centralização do poder e militarização constituiu fecundo terreno para o florescimento da nova doutrina que, oriunda da província da Judéia, viria a conquistar toda a extensão do Império, assim como modificar o curso do pensamento e da religião prevalecentes até então. Mas, para que conseguisse imporse, essa religião de caráter universalizante travou inigualáveis lides com a religião pagã, cultivada no âmbito privado sob os auspícios do pater familias, quando esta última ainda se debatia em resistência. Os cristãos, além do paganismo privado, enfrentaram a relutância dos imperadores romanos, que deram início a uma série de perseguições e matanças, que só permitiram o desenvolvimento sub-reptício do culto. As catacumbas tornaram-se os templos desta fase crítica de acomodação, onde predominou uma arte pictórica modesta, mas carregada de significativa simbologia (palma, cruz, âncora, ichtys). A invasão da vida privada como forma de repressão ao Cristianismo tornou-se prática constante.

Mudanças profundas operaram-se no seio da sociedade romana que se via impregnada pela moral estóica. Foi o início da filosofia da alma, onde o prazer era considerado contrário à razão, onde o homem era considerado submisso a uma esmagadora realidade mundana, igual ao seu semelhante e vigiado pela divindade única e superior. A antiga sociedade calcada no poder imperial inexorável e na fraca presença de uma doutrina espiritual universalizante viu-se sensibilizada pela moral estóica e em franco declínio cultural, pois o Império começou a apresentar seus primeiros sintomas de retração. Assim, tornou-se fácil compreender que, vencidas as primeiras dificuldades, foi rápida a difusão do Cristianismo por todo o Império.

Portanto, a Antiguidade Tardia correspondeu a um período de intensas modificações e crises sociais, assim como de gradativa diminuição da autoridade imperial correspondendo a um crescimento do poder religioso. A corrosão do modo de vida pagão iniciou-se com o estoicismo e foi perpetuado pelo Cristianismo (Ariès \& Duby, ob. cit, v. 1, p. 226-41). O século II d.C. já demonstrava a prevalência dos laços familiares da cognatio sobre os da adgnatio. Os patres tiveram seus poderes restringidos ao máximo, passando o direito a coordenar maior das relações sociais. A aristocracia, anteriormente empenhada na autopromoção, tornou-se introspectiva e hierarquizada. A caridade ensinada por 
Jesus Cristo, para ser executada, necessita do público, mas dele deve ocultar-se sob o perigo de não ser verdadeira. A virtude, agora, encontra-se na simplicidade de coração, na reforma íntima do próprio homem, que se encontra diante de um Deus que penetra no privado de cada coração e perscruta-lhe os segredos. Inicia-se um distanciamento com relação às paixões mundanas, às orgias e volúpias, às riquezas, assim como ao ócio. Esta verdadeira revolução social permitiu a humanização da situação dos escravos, da mesma maneira que modificou a estrutura educacional, tornando-a voltada para o ensino do medo a Deus, para a distância da cidade e de suas perdições, almejando o alcance da prática das virtudes divinas.

O Imperador Constantino, em 313 d.C., concedeu liberdade de culto e converteu-se ao Cristianismo. Mas, este fato representou apenas a consagração de uma situação quase que estabelecida por completo. A estruturação da Igreja Romana operava-se desde o século II d.C., aumentando seu poderio e sua representação, paulatinamente. A este tempo, basílica paleocristã era um templo arquuitetonicamente exuberante, obedecendo ao padrão de construção calcado na concepção artística greco-romana da época (formato de uma cruz). As festas públicas, os funerais e o sepultamento passam a vigorar em torno da Igreja que, exercendo a função solidária de auxílio aos pobres, recebe números donativos e contribuições. As riquezas anteriormente esbanjadas nos festejos, na promoção de espetáculos circenses e lutas de gladiadores são destinadas, agora, ao auxílio dos pobres através da sagrada Igreja. $O$ casamento passou a ser revestido de outras conotações; torna-se união consagrada por Deus, estável e perpétua para os cônjuges, que juram fidelidade recíproca. $\mathrm{O}$ perdão é ensinado como forma de quebrar a cadeia ininterrupta das "re-ações" surgidas no âmbito político em virtude das discussões; a vingança torna-se um ato condenável, contrário aos ensinamentos de Jesus; o espaço público e suas luzes desaparecem.

Os alicerces da Igreja Católica estavam completamente sedimentados quando se verifica a oficialização do culto por Teodósio em 395 d.C.. O mesmo imperador, quatro anos antes, teria, diante da fraqueza do gigantesco corpo, dividido o Império em duas partes: Império Romano do Ocidente (Roma) e Império Romano do Oriente (Constantinopla). A pressão dos povos bárbaro-germânicos provenientes da região setentrional da Europa, em decorrência do deslocamento dos hunos - sobre as fronteiras intensificou-se durante todo o século V, até o golpe final 
em 476 d.C., quando Roma é sediada e invadida (queda da parte ocidental do Império sob o domínio bárbaro).

Toda a dialética deste momento de transição e decadência aparece expressa na teoria de Santo Agostinho (354-430 d.C.). Filosoficamente, Aurélio Agostinho encontrava-se dentro de um período caracterizado pelo neoplatonismo de Plotino (III-VI d.C.). Sendo de orientação maniqueísta durante toda a sua juventude, além de retor em Catargo e em Roma, converteu-se ao Cristianismo em Milão para tornar-se, logo em seguida, bispo de Hipona. O conflito da fé, da conversão e do arrependimento por uma juventude desregrada, vem expresso em sua obra As Confissões, gênero monográfico muito difundido neste período. À pergunta - a crise do Império é conseqüência da adoção do Cristianismo? Santo Agostinho responde negativamente, através de sua elaboração teórica, consagrada em $A$ Cidade de Deus, de veemência incontestável. A fecundidade de seu pensamento apresentou como resposta aos inúmeros problemas do Império a idéia da caducidade do mundo. A história humana seria escrita em duas epopéias antagônicas: a epopéia da queda moral da humanidade e a epopéia ascendente do desenvolvimento material das sociedades. A primeira ter-se-ia iniciado com o pecado original de Adão e Eva, que teriam pervertido o significado da relação sexual, inicialmente pura, para a paixão voluptuosa. Daí então o sexo aparecer como algo condenável dentro de sua doutrina, uma vez que seria inadmissível este tipo de relacionamento na esfera angélica. Destarte, caminhando inexoravelmente para o Juízo Final, o mundo já apresentava os indícios primeiros de sua proximidade, momento em que todos seriam julgados na redenção final das almas. Este seria o caminho da Cidade do Homem, fundado sobre o egoísmo, diferentemente da Cidade de Deus fundada sobre a fé.

Não obstante, Agostinho vê na justiça e nas demais virtudes o elemento precipuamente determinante da sociedade e do Bem-Comum. Seu pensamento inaugura um período em que o conhecimento deverá estar completamente voltado para a descoberta de Deus e de seus segredos, uma vez que estabelece na quaestio mihi facto sum que a única forma de que o homem dispõe para o próprio conhecimento de sua essência se encontra em Deus. À pergunta - qui ergo sum ? - o homem facilmente desvenda os mistérios de sua natureza vendo-se animal racional, mas à outra quid sum? só pode encontrar resposta em um Deus detentor da suma sabedoria, conforme constata Hannah Arendt analisando a obra 
agostiniana. Também, a hierarquia e o organicismo prevalecentes durante toda a Idade Média em todos os planos sociais são heranças do pensamento do doctor ecclesiam, assim como se vê expresso nesta assertiva de sua autoria: "E, assim, juntamente com seu dom, maior ou menor, cada um receberá o dom adicional do prazer de não desejar mais do que tem" (feudo, guilda e mosteiro).

\section{Idade Média}

Contribuição sui generis foi dada por São Bento de Nursia (547 d.C.) para a estruturação da vida monacal e para o fortalecimento do corpo religioso que haveria de se expandir muito durante a Idade Média. Combatendo energicamente $o$ ciclo de difusão do estilo de vida eremita (egípcio), baseado no abandono da sociedade para a vida selvagem (silvaticus) com vistas a alcançar uma maior proximidade de Deus, São Bento organizou em suas Regras um conjunto de princípios norteados pelo convívio comunitário ecológico que permitisse a composição harmoniosa entre o corpo e a alma de cada um dos congregados. Os mosteiros, então, passaram a representar um ambiente de solidariedade, ajuda aos pobres, doentes, idosos, assim como local de refúgio para os perseguidos dentro da sociedade secular. Desta forma, a doutrina beneditina representaria a sistematização da ordem religiosa, tendo difundido os seguintes princípios:

- não martirização do corpo, mas utilização de boa alimentação e descanso indispensável (carnes de quadrúpedes eram vedadas);

- divisão das tarefas entre os monges, segundo as aptidões individuais;

- distanciamento do otium, luta para o aperfeiçoamento intelectual, espiritual e manual (ora et labora);

- manutenção do silêncio constante e da oração como forma de cultivo do homem interior;

- distribuição das atividades intelectuais, religiosas, agrícolas e artísticas em doses diárias segundo as estações do ano;

- cooperação com a sociedade laica;

- fraternidade com doentes, idosos, jovens e pobres;

- ausência de dominạ̧ão ou imposição (supervisão pelo abade era tida como relação fraternal). 
As invasões bárbaro-germânicas desde o século $\mathrm{V}$ e o assentamento destes povos em inúmeros reinos espalhados por todos os antigos domínios do Império Romano deram origem a uma nova forma de vida no mundo ocidental. $\mathrm{O}$ processo de aculturação foi intenso, desaparecendo os motivos romanos diante da arte decorativista adequada ao modo de vida nômade destes povos primitivos. A violência generalizou-se por todas as esferas sociais, ocasionando um estado constante de guerras e alta mortalidade masculina. A morte tornou-se fenômeno comum, de pouca relevância, diferentemente da concep̧̧ão a respeito da vida pósmorte, sempre motivo para temor pelo desconhecido. Algo que deixou marcas indeléveis no mundo ocidental foi o pudor bárbaro com relação ao sexo. Considerado verdadeiro tabu, o corpo era tido como inviolável, tanto que qualquer tipo de investida contra a higidez do mesmo era motivo de vultosas punições pecuniárias.

Portanto, o contato com a cultura e os costumes dos povos setentrionais europeus esfacelou a estrutura monolítica do Império Romano do Ocidente, originando o processo de feudalização. A posse da terra determinava o poder temporal e as relações, dentro de uma vida ruralizada, eram baseadas no comitatus e no colonato, institutos que regulavam as interações entre suserano e vassalo, assim como entre senhor e colono.

Também a influência bárbara se faz presente ao analisarmos o processo de privatização, onde cada feudo tornou-se responsável pelas suas propriedades (auto-suficiência), pela circulação de moedas próprias (costume merovíngio), pela construção de estradas para o transporte das mercadorias (costume escandinavo), da mesma maneira que pela defesa de seus territórios através do exército particular. Aliás, a cavalaria foi considerada uma verdadeira arte, prerrogativa da nobreza, dotada de códigos e regulamentos próprios; era a forma de convívio dentro de uma sociedade altamente violenta, a ponto de ter um crescimento vegetativo, além de uma expectativa de vida, muito baixos para o sexo masculino, o que acarretava a exaltação da força e da virilidade. Os grupos intermediários proliferaram-se: guildas, associações de homens em torno de determinadas tarefas comuns (paganismo); judeus, unidos em comunidades comerciantes; corporações, visando à organização da produção artesanal; mosteiros, como forma de fuga à violência social. 
Foi neste ambiente hostil que as ordens religiosas se difundiram pelos cantões isolados e florestas inexploradas, aspirando a um modo de vida pacífico e virtuoso, representando pequenas porções da Civitate Dei na Terra. Travando lides incessantes contra costumes bárbaros e pagãos, a Igreja Católica procurou a cristianização como modo de aproximação entre o convertido e Deus; transformou todas as crenças em um dualístico confronto entre as forças do bem e do mal; introduziu o entendimento da morte como fenômeno sagrado; combateu as fantasias que se perpetuavam através da bruxaria e da alquimia (ritos e poções que procuravam 0 aumento da fecundidade da mulher, maior virilidade para $o$ homem...). Este período, que se estende de 476 a 800 d.C., caracterizou-se pela generalização da ignorância, pelo desaparecimento da cultura romana e das obras pagãs. Os mosteiros tornaram-se os únicos responsáveis pela perpetuação da arte e da cultura. A aparência de pureza e austeridade estampada no semblante dos silenciosos monges, assim como a detenção de segredos para a salvação da alma do pecador, de obras raras, de singulares manuscritos e do ensino monacal para a nobreza, dotaram a Igreja Católica de um grande prestígio social, conferindo-lhe poderes temporais inigualáveis por longos séculos. Inspirando-se nos princípios beneditinos, a Igreja desempenhou importantíssimo papel de transmissão da cultura na Idade Média.

É imprescindível destacar que, durante o reinado de Justiniano, o Império Romano do Oriente experimentou um periodo de grande prosperidade. Empenhado em deter o avanço bárbaro, o Imperador conseguiu expandir as fronteiras e estabelecer novos pontos de difusão da fé católica dentro dos domínios ostrogodos, v.g., Ravena. Perpetuando fielmente seu dever, conseguiu dotar o Império de expressão e majestade fulgurantes, atestadas nos grandes monumentos religiosos erigidos neste período que primam pela exuberância dos mosaicos (Basílica de Santa Sofia). O Direito Romano compilado no Corpus Iuris Civilis (Triboniano) tornou-se um dos maiores legados à posteridade.

No Ocidente, o advento de Carlos Magno tornou-se um verdadeiro marco dentro da Alta Idade Média. Coroado Imperador pelo papa Leão III, oficializou a união entre o poder real e o papal. Responsável pela reorganização do Império e pela imposição do Cristianismo, deu novos impulsos ao ensino e à arte. Fundaram-se as scholae monacais, catedrais e palacianas, assim como diversas oficinas artísticas que produziam manuscritos sob encomenda, traduziam as obras 
pagãs, aprimoravam a arquitetura, a arte da ourivesaria e da miniatura. Sob os seus auspícios, fundaram-se mosteiros responsáveis pela acolhida dos viajantes. O pudor bárbaro com relação à nudez transferiu-se para o mundo católico, quando o Imperador proibiu o banho de imersão do batismo e a exibição de esculturas de Jesus crucificado despido de vestimentas. De maneira geral, Carolus Magnus representou um grande símbolo do revivescer cultural em meio à caótica organização medieva.

Com a morte do Imperador franco, a aurora artístico-cultural esmoreceu para que fosse retomada após o fim da Alta Idade Média (século X), em princípios do século XI. Os motivos greco-romanos cristalizaram-se no estilo românico que, ao lado de um movimento de multiplicação de mosteiros a partir de Cluny (910), difundiu-se por toda a Europa. Assim como abadias, conventos e comunidades monacais, pulularam construções torreadas e de ameias fortificadas, representações da habitação da nobreza castelã. Aliados do incrível poderio da faustosa Igreja Católica, os nobres procuraram abrigar no seio de suas famílias clérigos e outros servos de Deus com vistas a descobrirem os segredos da salvação, pois enquanto estes rezavam por suas almas, eles guerreavam. $\mathrm{O}$ século $\mathrm{XI}$ aliou $\mathrm{o}$ poder militar à fé religiosa, ao mesmo tempo que permitiu o alívio das pressões de uma população crescente e da falta de alimentos através das Cruzadas de reconquista da Terra Santa. O afastamento da nobreza e do clero com relação ao Imperador acentuou o primado do privado sobre o público, numa época em que este último era definido negativamente como tudo aquilo que não estivesse in patrimonium. $\mathrm{O}$ privado era a esfera inatingível pelos poderes imperiais, não se limitando à clausura do ser individualizado, mas sendo entendido como o conjunto gregário de indivíduos em uma célula mínima representativa: a comunidade (guilda, mosteiro, feudo...). Os atritos entre o poder temporal e o espiritual intensificaram-se; Gregório VII excomungou Henrique IV em 1076.

A expansão econômica, o desenvolvimento de novas técnicas agrícolas, o florescimento das cidades e da burguesia comerciante, a renovação dos meios de transporte, a retomada do fluxo de trocas cambiais, assim como os contatos constantes com o Oriente passaram a constituir a alma de um corpo político renovado diante da experiência cosmopolita. É nesse ínterim que as obras aristotélicas traduzidas e influenciadas pela filosofia árabe (Averróis) retornaram ao mundo europeu através dos espanhóis. Ao mesmo tempo, a corrup̧̧ão do clero deu 
ensejo ao surgimento de ordens mendicantes e que combatiam a opulência da alta hierarquia eclesiástica, assim como os abusos e desregramentos presentes nos mosteiros. Seria vendar os olhos à realidade não reconhecer que muito se distanciaram da pureza dos preceitos beneditinos os clérigos, que deram vazão ao mundo de paixões ociosas reinantes no inferno do coração de homens pouco afeitos a suportarem o conjunto de imposições necessárias a uma vida orientada nos ensinamentos divinos. Destarte, surgiram os dominicanos e franciscanos procurando imprimir novos rumos ao mundo religioso católico.

Santo Tomás de Aquino (1227-1275), após vencer a relutância da família, que se opunha à sua conversão para a ordem dominicana (recém-fundada e de pouco prestígio social), empenhou-se no ensino teológico em Paris e travou contato com as traduções latinas dos textos gregos de Aristóteles e com as tendências filosóficas do período que suscitavam incriveis debates (nominalistas e realistas). Cumpre ressaltar que a aceitação das obras aristotélicas foi empreitada de difícil consecução, uma vez que pontilharam os expurgos durante todo o século XIII $(1210,1215,1231$ e 1277). Essas prevenções se deviam às traduções feitas pelos árabes que, além de traduzirem, comentavam os textos originais imbuídos de teorias malvistas pela Igreja Católica. Mas, o Aquinatis conseguiu estruturar sua monumental obra teológica, a Summa Theologiae, sobre a filosofia aristotélica, adequando-a à doutrina cristã, à aceitação do Deus uno e onipotente. A Suma Teológica foi um gênero de exposição sistemática da doutrina teológica muito desenvolvido no século XIII. A divisão da obra em questões seguia a ordem do ensino teológico da universidade, ambiente em que ministrou por longos anos. Não obstante, sua teoria não se resume na obra destinada ao ensino acadêmico, mas alarga-se por todas as suas outras construções.

Retomando os principais pontos da filosofia de Aristóteles, o Doctor Angelicus ressalta a necessidade da vida na pólis para que se alcance a felicidade humana, pois esta, calcada em uma estrutura jurídica capaz de garantir a paz social, deve procurar promover o aprimoramento humano segundo um estilo de vida virtuoso. A lei deve servir para o alcance do Bem-Comum. $O$ bem particular ordena-se ao bem do todo, pois a parte existe para o todo e não o todo para a parte (bonum particulare ordinatur ad bonum totius sicut ad finem, ut ad perfectum). Também a ordenação do homem à civitas não é feita segundo todo o seu ser ou todas as coisas que lhe pertencem. É na justiça e nas demais virtudes que está o 
elemento precipuamente determinante da sociedade e do Bem-Comum, sendo neste ponto particular coincidente a teoria agostiniana e a tomista. Ainda orientado pela teoria do insuperável estagirita, o Aquinate entende ser o homem social por natureza, sendo a família a primeira e mais natural das sociedades, depois, adequando-se ao convívio cívico como homem político.

Utilizando-se da clássica partição, retoma o princípio das quatro causas determinantes da estrutura social:

- causa final: Bem-Comum. Este só pode ser alcançado pelo convívio social organizado por uma ordem jurídica voltada para a manutenção da paz social, onde cada indivíduo procura viver segundo a virtude de modo a construir seu próprio progresso, assim como de todos os seus semelhantes;

- causa eficiente: distinção entre homem e animal, onde o homem é magis communicativus e, por ser formado pelas substâncias do mundo natural, tem direito à vida, por ser igual a um animal; biologicamente, tem direito a reprodução; mas por ser racional congrega-se no convívio social;

- causa material: famílias e grupos intermediários integram a sociedade política;

- causa formal: formas de governo. São: monarquia, aristocracia e politéia, podendo ser degeneradas em tirania, oligarquia ou em democracia. Ideal: monarquia aristodemocrática com representação política, participação e direito à insurreição legítima à tirania.

Deste modo, conseguiu transcender à sua época ou à vinculação com a escolástica, erigindo um monumento filosófico-doutrinário inigualável, constituindo verdadeira philosophia perennis. Seus conceitos e princípios não se limitam ao momento histórico medieval, representando sempre um vivo manancial filosófico.

$\mathrm{O}$ período medieval primou, portanto, pelo cultivo da vita contemplativa a que se resumiu a vita activa. Ao contrário da Antiguidade grecoromana, a ação política passou a ser considerada indigna, devendo o homem filósofo dedicar-se exclusivamente à contemplação. É a apolitia. A contemplação deveria ser um exercício para que se chegasse à Verdade, só possível com a Revelação Divina; e o princípio agostiniano de que a filosofia deveria nortear o homem exclusivamente para o conhecimento de Deus, que iria prevalecer por todo o período medieval. A necessidade do silêncio, da oração e da introspecção, aliada à 
ausência de um espaço público propício para o desenvolvimento das ações políticas, permitiu que a apolitia fosse aceita como um princípio irrefutável de vida (Hannah Arendt, ob. cit., p. 22-3).

Mas, retomando a seqüência histórica de nossa narração, presenciamos o amadurecimento, entre os séculos XII e XIII, da arte gótica que, juntamente com sua característica primordial, a verticalidade, representaria a expressão máxima do poder da Igreja Católica no mundo ocidental. A esta época, os burgos pontilhavam por todos os cantos da Europa onde fervilhavam rotas comerciais que inundavam o Velho Mundo de especiarias e tecidos orientais. $\mathrm{O}$ Direito Romano, material básico de estudo dos glosadores medievais, agia como fermento da desagregação dessa sociedade, pois, sendo o resultado do período imperial romano, caracterizado pelo militarismo, pela centralização e pela dominação burocrática, só poderia vir a representar um corpo estranho dentro de uma estrutura pluralista, repleta de variegadas comunidades intermediárias e independentes, v.g., as guildas, as corporações de ofício, os mosteiros, os clãs... A desordem generalizava-se com a decadência da cavalaria medieval e com a proliferação da guerra mercenária dirigida pelos condottieri. Tornava-se necessária a centralização política, a unificação das fronteiras e a regulamentação das normas dos que viriam a ser os Estados Nacionais.

\section{Idade Moderna}

Maquiavel e Bodin despontaram no século XVI, afirmando a necessidade do poder absoluto para a manutenção da organização das sociedades, introduzindo-se, pela primeira vez na história, o conceito de soberania nacional inviolável e indivisível. As artes desenvolveram-se, retomando as inspirações greco-latinas, enquanto o homem, ávido de liberdade, aspirava ao individualismo e ao antropocentrismo. Desidério Erasmo foi o filósofo do período que combateu veementemente as instituições religiosas vigorantes, apontando, através de um estudo analítico, as corrupções dos objetivos iniciais de um corpo eclesiástico que evocava uma falsa santidade. Os embates políticos e religiosos da época de Henrique VIII compunham uma situação caótica de degeneração na Inglaterra, incumbindo-se Sir Thomas More de idealizar sua Utopia (ou+topos= lugar imaginário), mundo que escapava às ambições e vilanias da sociedade inglesa de 
sua época, propondo o retorno à vida comunitária e natural, muito inspirada na República de Platão e em alguns princípios de São Bento de Nursia.

Do ponto de vista religioso, a Reforma Protestante, iniciada com a divulgação das 95 teses por Lutero e impulsionada pela ajuda de Calvino, representou um grande abalo para o sistema católico, resultando numa série de embates religiosos que se prolongaram pelos séculos XVI e XVII. As grotescas lides entre fanáticos religiosos, que conduziam sua fé dogmática ao ponto da guerra, não pouparam a população civil, cometendo atrocidades inimagináveis. Procurando regulamentar esta situação pela diminuição da violência e da barbárie, Hugo Grotius escreve sua obra $O$ Direito da Paz e da Guerra, consagrada como instituto de Direito Internacional.

O século XVIII inicia-se pelo lançamento de inúmeras obras de crítica à realidade e à moral reinantes, procurando o combate aos resquícios das falidas instituições religiosas. A poesia passa a ser tomada, sob a inspiração dos autores clássicos Horácio e Juvenal, com vistas à sátira e à comédia sobre temas variados, como: romances sentimentais, otimismo, maus pregadores, vida local ou regional... Miguel de Cervantes, com seu dom especial de recriação crítica da realidade, torna-se tema de estudo. Enfim, esse é o século da revisão dos valores até o momento aceitos sem questionamento, sendo a majestade da legislação e a santidade da religião os principais focos de atenção do pensamento europeu.

A emancipação das idéias e a formação de uma nova mentalidade conduzem inevitavelmente 0 , homem à busca da felicidade, contribuindo para isto, inúmeros autores. A expressão que consagra este período é século das luzes devido à predominância da razão, da experimentação como forma de objetivação e comprovação da verdade (les lumières, iluminismo, illuminato, siglo de las luces). Diderot e D'Alembert enalteciam o valor do surgimento das luzes de diversos focos, dissipando a sombra e as trevas que permeavam a razão anterior a esse período. As influências de Locke e Boyle se fazem sentir por todas as partes.

Deus não foi de forma alguma esquecido ou negligenciado pelos enciclopedistas célebres, mas foi buscado segundo a capacidade racional de entendimento, dissipando-se as trevas, o fanatismo e a cegueira. Para isso muito contribuiu a introdução do protestantismo e sua ética educacional própria em alguns países que passaram a se destacar pela glória da filosofia racional, desvinculada de qualquer dogma teológico. A religião foi posta a prova, a exame 
por todos. Uma Igreja Católica que pregava pela boca de seus padres a eterna bondade e suprema paciência do Ser, crença de um homem de fé, conduzia os homens a um entendimento supersticioso numa divindade vingativa e capaz de ao próprio homem destruir, crença de um fanático religioso, algo que aos olhos da razão torna-se evidente contradição, constituindo uma das inúmeras conquistas deste século das luzes (desmitificação do ensino do medo). A política sanguinária da Igreja que pregava a santidade e vivia do charlatanismo, do fanatismo, da violência, da ganância e muito mais preocupada com questões seculares passou a ser rejeitada pelo homem instruído e livre de dogmas ou influências místicas. David Hume e Schmidt ativamente participaram desse processo de racionalização da deidade.

A difusão de manuscritos clandestinos, da propaganda oral da filosofia e da razão, a decadência da eloqüência religiosa e a expulsão dos jesuítas da França são provas do alvorecer e do esmorecer dos espíritos fanáticos.

Uma vez refutadas as dúvidas religiosas do homem anterior ao século XVIII, surgiram os estudos a respeito da natureza e de todas as suas manifestações, do homem e de suas formas de expressão e relacionamento na história. Discussões inúmeras foram travadas entre deístas e teístas, sendo os primeiros devotos à divindade exclusivamente e os segundos, à vida após a morte, à existência da alma e suas manifestações. Outras questões suscitaram discussões envolvendo também os ateus.

As ciências naturais, o direito natural, a teoria hobbesiana proliferaram-se com muita intensidade. Os novos movimentos filosóficos tendiam para a formulação de uma teoria moral ilustrada, pendendo para a defesa de direitos naturais e de qualidades virtuosas a serem desenvolvidas pelo homem para que alcançasse a felicidade. A idéia de moral retratava com todas as cores o quadro ideológico da época.

A concepção de governo justo e bom logo se desligou da aplicação única de um modelo (monarquia, democracia ou república) para filiar-se ao conceito de busca da felicidade e do bem-estar para um maior número de súditos possível. Surgiram mesmo teorias que fundiam os diversos modelos para que se alcançasse o ideal de governo para o povo. A difusão da cultura e da ciência atingiu todos os ramos do saber humano e visava à vulgarização, entre o povo, de conceitos científicos primordiais a todo cidadão. A educação foi o método de aquisição desses 
conhecimentos. Os temas literários aprofundaram-se no estudo da sociedade, analisando temas diversos, a saber, a história, a mulher, a ópera, o homem de letras, a literatura e o governo, a filosofia prática, a maçonaria, o burguês...

$\mathrm{A}$ natureza veio agregada às idéias de razão, bondade e otimismo. A política sofreu reformas e passou a ser o palco das novas idéias (despotismo esclarecido). Para que o governo pudesse estar sobre bases sólidas, deveria fazer-se acompanhar de leis que garantissem a liberdade, o que se expressa classicamente dentro da doutrina francesa como constituinte do princípio: Les lois sont les rapports nécessaires qui dérivent de la nature des choses. Dessa forma, o turbilhão racional desse século mudou os destinos da Europa e do mundo, assinalando o ressurgir da cultura e a difusão da ciência e do pensamento, a laicização dos conhecimentos científicos e a eliminação da dominação espiritual absoluta sustentada pela ignorância e tutelada pela Igreja Católica.

Personalidades: Hume, Diderot, D'Alembert, Locke, Rousseau, Montesquieu, Erasmo de Roterdam, Hobbes, Voltaire, Descartes, Bacon ...

O Iluminismo conferiu o respaldo intelectual para o movimento de revolta contra o Ancien Régime. O campesinato esmagado pelo peso dos encargos impostos por uma nobreza ociosa, funcionou como fermento popular ao conjunto de idéias libertárias que culminariam com a Revolução Francesa, conduzida pelo fervor religioso às últimas conseqüências, diante das teorias revolucionárias e jacobinas.

Desta forma, a monarquia absoluta é derrubada como modelo político e forma de governo. A maior expressão filosófico-política monarcômana, Thomas Hobbes, perdeu seu vigor diante das teorias renovadoras de John Locke e JeanJacques Rousseau. Os impetuosos ventos revolucionários conseguiram deitar por terra a idéia de que o homem passava de seu estado natural de liberdade para 0 estado civil, devendo alienar todos os seus direitos naturais e submeter-se integralmente à proteção do soberano. Aspiração que não tardou a tornar-se restrita à cronologia de específicas e cristalizadas circunstâncias históricas. Locke e Rousseau enriqueceram o mundo filosófico - e seu vocabulário próprio adicionando termos e pensamentos que estruturaram a base da filosofia na Idade Moderna. $O$ primeiro autor consagrou a necessidade da passagem do estado natural para o convívio contratual em busca da proteção dos direitos naturais imanentes a cada indivíduo; o segundo concretizou a maior aspiração ideológica da burguesia da 
época: o homem integra-se socialmente ao contrato em favor da vontade geral, procurando a liberdade dentro do Estado. Desta maneira, cada ser autônomo estaria privilegiado pelo segurança e pela liberdade no convívio social.

Não se pode omitir a Revolução Americana (1776) como acontecimento relevante nesse processo de ruptura com as antigas forças sociais $\mathrm{e}$ de formação de uma nova conjuntura que institucionalmente seria regida pelo Estado Liberal Constitucional. Mudanças incriveis surgiram com os processos de adaptação das estruturas políticas aos limiares de uma ordem renovadora de laicização da cultura e dessacralização da sociedade.

\section{Idade Contemporânea}

O intenso combate proclamado à Igreja desde a Reforma Protestante e coroado com o Iluminismo oitocentista conduziu o homem do século XIX a uma reiomada do ideal dos laços religiosos. Chateaubriand empenhou-se em revigorar alguns preceitos religiosos salutares e indispensáveis dentro do convívio humano, enquanto Augusto Comte revitalizou e mesclou a religião com o positivismo e com o racionalismo. Aliás, dentro de um contexto de alvorecer das ciências naturais e exatas (Biologia, Química, etc.) e de teorias inovadoras (determinismo, evolucionismo...), este último autor tornou-se o empreendedor de uma forma de abordagem e estudo dos problemas humanos, lançando as bases da Sociologia.

A participação dos valores religiosos e a respectiva importância na evolução das sociedades tornaram-se motivos de estudo para Max Weber e Émile Durkheim. Dedicados à descoberta das causas que provocaram a grande fissura no corpo do mundo ocidental após a Revolução Francesa, esses autores descobriram a relevância atribuída pelo ser humano ao culto místico e sua imbricação com o conjunto de valores sociais. A ruptura com a tradição, a desmitificação de valores, a dessacralização da cultura e a intensificação do racionalismo são algumas consequiências do processo de formação de uma nova realidade ocasionado pela Revolução Francesa. É de se ressaltar que esta forma de modificação e renovação social encontrou sua primeira manifestação em 1789, na França, pois, anteriormente, as inovações eram introduzidas através da rebelião. Além de repercussões no âmbito social, o século XVIII também trouxe inovações 
tecnológicas com a Revolução Industrial, que modificou todo o sistema de relacionamento entre o homem e a produção.

Todas essas transformações deram ensejo à multiplicação de inúmeras teorias, a saber, anarquistas, anarco-sindicalistas, socialistas, comunistas... que marcaram todo o século XIX. A emergente ciência sociológica expandiu-se em suas teses de estudo de inúmeros problemas sociais que pulularam por todas as esferas do convívio humano.

Foi desta forma que o Estado encontrou suas bases no surgimento da Idade Moderna (Westfalia, 1648), caracterizando-se pela imposição de uma fonte única capaz de regulamentar a vida dos indivíduos: a estatal legal. $O$ pluralismo medieval cedeu lugar ao monolitismo do Estado Liberal. Consagrou-se a forma de dominação legal-racional descrita por Weber como consequêencia do processo de racionalização de todos os campos do conhecimento humano, caracterizando-se pela impessoalidade, pela burocratização e tecnicização do relacionamento entre dominante e dominado. O Estado passa a representar a ordem, assim como a organização jurídica soberana, que tem por fim o Bem-Comum de um povo situado em território delimitado. Destarte, este corpo jurídico incumbiu-se de alcançar a melhor forma possivel de convívio entre os seres humanos, buscando o BemComum através de mecanismos racionais.

Mas o século XIX já apresentava indícios da falibilidade da aplicação integral deste modelo. $O$ indivíduo encontra-se reduzido a $1 / 3$ de sua capacidade, transformado em um ser pouco participativo, pouco informado, escravo de sua sobrevivência e distante de sua posição ativa no espaço público em meio à pluralidade de seus semelhantes, estando a ação política inutilizada diante do imenso aparato burocrático estatal. $O$ âmbito público, conforme a análise arendtiana da problemática contemporânea, notoriamente o espaço da ação política, vê-se reduzido a local de desenvolvimento unicamente de atividades relacionadas ao trabalho, confundido com o labor responsável pela manutenção da vida. Ademais, a não-identificação de valores no espaço público, entre os indivíduos, faz com que se encontrem unicamente em função da aquisição monetária, sendo cada um visto e confundido com a própria mercadoria que produz e não como ser humano dotado de sentimentos. O próprio Estado, distanciado de seus objetivos fundamentais de proporcionar o enriquecimento do convivio social, tornou-se palco de encenação e projeção de alguns indivíduos ou mecanismo de veiculação 
ideológica para a conquista do poder. A representatividade restringiu-se ao mínimo, ao mesmo tempo em que a ação partidária teve suas funções iniciais pervertidas. Não se pode omitir que a técnica tem permitido transmissão de imagens que funcionam como mecanismos de falseamento do espaço público pela ideologia, onde prevalece o senso comum sobre qualquer manifestação da lógica ou do pensamento crítico.

Por outro lado, a ampliação das atividades comerciais ocasionou intensa competitividade, que culminou com disputas entre os paises. $O$ século vivenciou o imperialismo sobre a África e a Ásia que, assim como as duas guerras de alcance mundial do século $\mathrm{XX}$, deixariam marcas profundas na sociedade, expressão da ganância pela dominação. Da mesma forma, a Revolução Russa de 1917 atestou a consagração do modelo revolucionário como forma de imposição do poder.

O mesmo conjunto de benefícios técnicos alcançado com o aperfeiçoamento técnico das ciências, que foram utilizadas estrategicamente pelas forças bélicas nas diversas guerras que pulularam por todo este século, é capaz de pôr fim à existência do homem sobre a Terra (capacidade humana de autodestruição). E é este mesmo tecnicismo responsável pelo isolamento dos seres em seus próprios mundos. Parece que aqui ainda cabe assinalarmos a veracidade dos escritos de Santo Agostinho, que afirmava ser a história humana escrita em duas epopéias: uma ascendente, correspondendo à evolução material pela aplicação da criatividade para a melhoria da condição de vida; outra descendente, correspondendo à involução moral devida à atrofia da capacidade de perpetuar os sentimentos que mais caracterizam a sua essência. A reificação dos valores em uma sociedade que só atribui importância às mercadorias tem adstrito o homem ao enclausuramento na vida privada, onde surgem e desaparecem indivíduos, sem que sejam percebidos, devido à ausência de um espaço público humanizado e propício à participação e à eternização de sua passagem pelo mundo através de ações memoráveis.

A máquina tem substituído o pensamento que, em detrimento da humanidade, verdadeiramente desapareceu da vita activa, apesar de ser fundamental para o futuro do homem e de ser norteador dos destinos dados à sua capacidade racional. Materialmente o homem está realizado, mas encontra-se 
distante de alcançar a felicidade e até o Bem Comum (Arendt, Hannah, ob. cit., p. 9-14).

Mas, apesar de tantos problemas advindos de uma sensível ruptura com o passado, novos princípios tem surgido ao lado da retomada de outros antigos. A ecologia resplandece como forma de defesa da natureza e busca de uma integração maior entre o homem e o meio ambiente. A revalorização dos laços familiares tem permitido a reabilitação de um núcleo essencial mais participativo dentro da sociedade. A Igreja tem passado por processos incríveis de transformação, tornando-se membro atuante na tentativa de minorar os efeitos dos variegados problemas de proporção social. Neste caminho de procura da significação de suas aflições, o homem certamente encontrará um valor que possa representar a âncora para a embarcação que vive momentos tempestuosos na atualidade, encontrando-o talvez no recôndito de algum ensinamento de um passado longínquo.

\section{BIBLIOGRAFIA}

AGOSTINHO, Santo. "Confissões; De magistro" in Os pensadores; trad. de Angelo Ricci. São Paulo : Abril Cultural, 1973.

ARENDT, Hannah. A condição humana; trad. de Roberto Raposo. Rio de Janeiro : Forense Universitária, 1989.

ARIĖS, Philipe \& DUBY, Georges. História da vida privada; trad. de Hildegard Feist. São Paulo : Companhia das Letras, 1990.

BENTO, São. A regra. Rio de Janeiro Lumen Christi, 1980.

COPLESTON, F C. El pensamiento de Santo Tomás; trad. de Elsa Cecilia Frost. México - Buenos Aires : Fondo de Cultura Económica, 1960.

CRETElla JR., José. Novissima história da filosofia. São Paulo Bushatsky, 1967.

DALLARI, Dalmo de Abreu. Elementos de teoria geral do Estado. São Paulo Saraiva, 1977.

JERPHAGNON, Lucien. História das grandes filosofias; trad. de Luís Eduardo de Lima Brandão. São Paulo Martins Fontes, 1992. 
NISBET, Robert. Os filósofos sociais. Brasília : Unb, 1982.

PLATÃo. "Diálogos" in Os pensadores. São Paulo : Abril Cultural, 1972.

PLATON. Oeuvres complètes; publiées sous la direction de Émile Saisset. Paris :

Bibliotèque Charpentier, s.d..

PROENÇA, Graça. História da arte. São Paulo : Ática, 1990.

ROBINSON, James Harvey. A formação da mentalidade. São Paulo : Nacional, 1940.

RUSSELL, Bertrand. História da filosofia ocidental; trad. de Bueno Silveira. $3^{\mathrm{a}}$ ed. São Paulo : Nacional, 1969. 